\title{
Methodological principles of the organization of reengineering in construction (capital construction facility reengineering and technological process reengineering)
}

\author{
Lyubov Maslova*, Sergey Sborshchikov, and Elizaveta Kochenkova \\ Moscow State University of Civil Engineering, Yaroslavskoe shosse, 26, Moscow, 129337, Russia
}

\begin{abstract}
As practice shows, in conditions of crisis organizational problems and development issues, when accumulated contradictions lead to the competitiveness decline and loss of consumers, it is proposed an application of methods of reengineering, implementing turning around enterprises, organizations, companies through moving to a new quality level and modernization of the previously implemented engineering solutions of the functioning facility. The goal of the work is to find organizational forms of quality transformation of the solutions, having an anthropotechnical genesis (technical, technological, organizational, managerial etc.) through capital construction facility reengineering and technological process reengineering solutions. Literature sources and current construction standards analysis is carried out to implement the goal. Methods of the system analysis and management, comparison, expert evaluation are used. General definitions of the reengineering from Russian and foreign sources are given in the article. Criteria and factors of the reengineering events classification at the «construction facility construction site» level are justified, the project of capital construction facility and technological process reengineering is set out, the capital construction facility reengineering structure is described, pattern solutions of the capital construction facility reengineering are formed, distribution of the reengineering types according to the stages of the life circle of the capital construction facility is presented. The structure of the capital construction facility reengineering standards is given and perspective directions of the information and analytical support development are indicated in the article. In the conclusion the fact, that reengineering is an effective mechanism of forming a comfort living environment, is justified based on the science and technology achievements, customer inquiry and most complete satisfaction, as well as the creation of the competitive edge of not only separate domestic construction organizations, but also the whole national construction field.
\end{abstract}

\section{Introduction}

There are two basic definitions of reengineering in special literature [1-6]:

\footnotetext{
* Corresponding author: MaslovaLA@mgsu.ru
} 
1) turning around enterprises, organizations, companies through moving engineering to a new level;

2) modernization activity of the previously implemented engineering solutions of the functioning facility.

Modern production systems organization paradigm is characterized by use of methods of its quality transformation - reengineering. The purpose of reengineering is finding trajectories of the system or facility development, they should be characterized by stability, reliability and efficiency. Making decision on reengineering, including capital construction facility reengineering, is a responsible and labour-intensive business, demanding accounting a lot of various factors, as well as analyzing large amounts of data. In this regard, information and analytical support of reengineering is taking a particular importance and place in the whole system of the corporate level investment-construction field.

\section{Methods}

Use of reengineering in construction has good perspectives, connected both with traditional application as investment-construction business process reengineering [7-10] and new directions of use at the corporate level [11,12]: capital construction facility reengineering and technological process reengineering.

Reengineering measures of the corporate level involve quality transformations of the organization, for example: structure transformations by means of application of project management and engineering construction scheme, as well as virtual offices when designing. [13-17] It is necessary to mention, that reengineering is acquiring a synergistic and multiplicative effect, affecting not only investment-construction field, when the interests of the state and private sector coincide. [18-20]

\section{Results}

Quality transformation of the capital construction facility (i.e. its reengineering) is connected not only with change of uses, architectural, space planning, structure, engineering services solutions, aimed at creating a comfortable living environment, but also with an effective implementation of the processes and activities of these transformations, based on progressive methods and organization of both new construction and capital construction facility renovation (i.e. technological process reengineering).

The necessity of performing one or another type of reengineering measures at the capital construction facility level (fig.1) is determined by follow criteria:

1. Efficiency of functioning;

2. Regulatory compliance;

3. Serviceability, technical condition of structures and equipment;

4. Rationality of methods and way of organization of work and job practices according to labor expenditures, period and costs.

Criteria 1,2,3 determine the necessity of quality transformation of the capital construction facility (capital construction facility reengineering), and criterion 4 points at technological process reengineering.

These criteria are directly related to reengineering factors, characterizing:

1. Functional use, job practices and service technology;

2. Architectural and space planning solutions;

3. Structure solutions and engineering services;

4. Organizational and technological solutions. 
Reengineering criteria may be parametrically decomposed later by dividing them into functional, regulatory, operational and economic groups of indicators.

Reconstruction, technical re-equipment, repurposing, renovation (major overhaul) may be considered reengineering measures of the capital construction facility in the context of the research.

Current construction standards give them clear definitions except for repurposing, that may be interpreted as reengineering measure, including reconstruction and technical reequipment processes when completely or partly changing functional purpose of the building, facility.

Unlike capital construction facility reengineering technological process reengineering has different reasons and qualification. In the first case the object, to which the impacts are directed, is a building or facility, that is tangible, in the second case it is a set of sequential operations, united by one goal, i.e. abstract category.

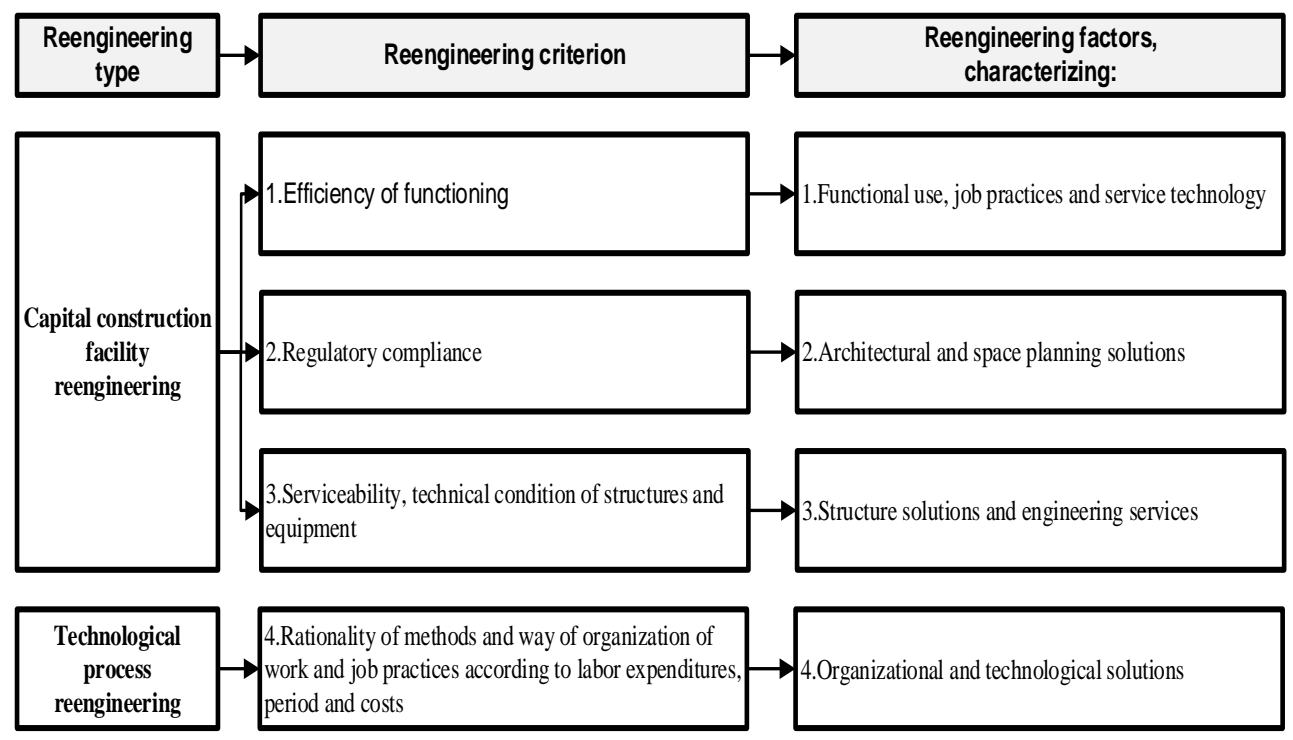

Fig.1. Criteria and factors of reengineering measures at the «construction facility - construction site» level

The reason for technological process reengineering is an application of the results of the science and technology development in practice, for example: an emergence of new materials almost immediately causes development of new technologies, thus the dependence «product novation $\rightarrow$ technological novation» implements. [21, 22]

Thereby, technological process reengineering as its quality transformation is primarily aimed to increase productivity by:

1) use of new materials, structures, that have improved characteristics in comparison with the traditional ones (for example: lighter, stronger, less thermally conductive, etc.);

2) new organizational schemes and technologies, which are based on the rational combination of processes and time reduction for the organizational and technological breaks;

3) new equipment, allowing to perform the same work or set of works for shorter periods of time, for example, due to reduction time for working cycle or increase of the value of the main parameter; 
4) complex mechanization, automation and robotization in both the erecting of particular parts of the building, facilities and the whole capital construction facility, for example as a consequence of additive technology application.

And as a consequence of these directions implementation, it is a decrease of not only standardized, but also not standardized labour costs, as well as hidden losses reduction and construction products quality improvement.

Unlike technological process reengineering, described above capital construction facility reengineering does not directly depend on the S\&T development, but implements it, as a rule, through changes in standards and ensuring the economic efficiency of the capital construction facility.

If the capital construction facility is considered the centre of the investmentconstruction activity system at the corporate level, on which all impacts are focused in one way or another and which is a quintessence of construction products, then the following elements may be identified in the capital construction facility reengineering (fig.2):

1. technical condition of the facility, as a result of its maintenance;

2. regulatory and teaching materials;

3. economic efficiency of the maintenance;

4. informational and analytical support;

5. Design and construction.

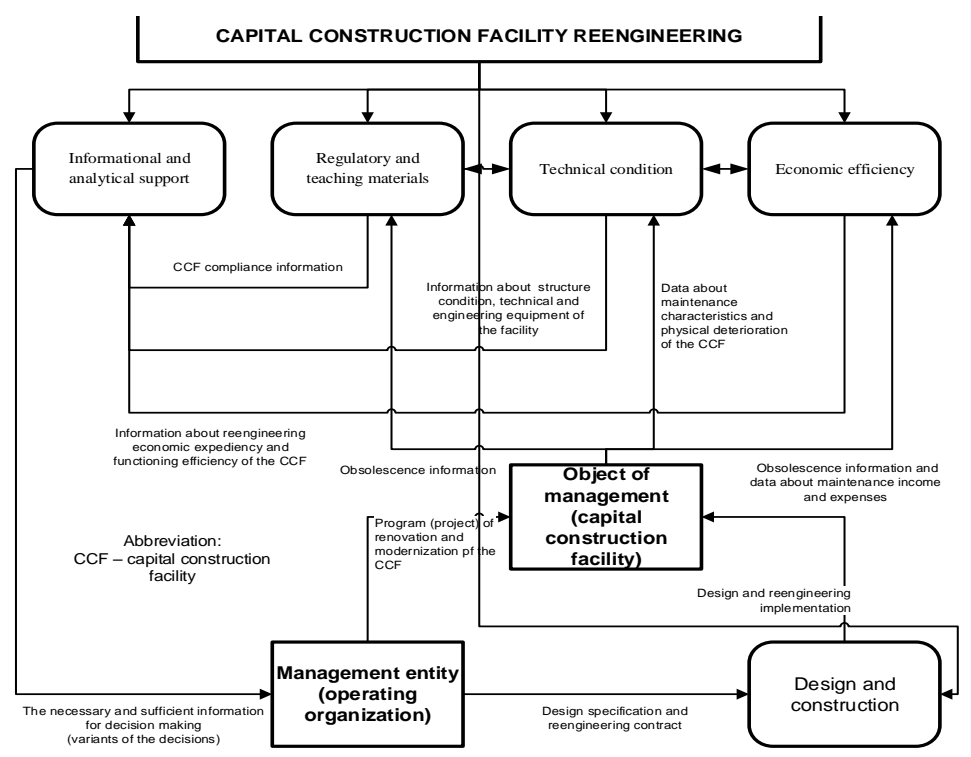

Fig.2. The structure of the capital construction facility reengineering

The quality transformation of the capital construction facility assumes availability of the necessary and sufficient information about the building, facility, not only its technical, but also economic aspects of the operation. This fact points at the importance of the informational and analytical aspect of the capital construction facility reengineering. On the one hand, the information, that accumulates and is revised in it, is:

- information about structure condition, technical and engineering equipment of the facility;

- information about functioning efficiency of the capital construction facility; 
- capital construction facility compliance information.

On the other hand, the information about reengineering economic expediency, as well as the information for decision making (variants of the decisions) on reengineering activities of the capital construction facility are formed in this subsystem, technical and economic features are formulated for further application in the design specification at the «design construction». [23]

So, it is possible to form capital construction facility reengineering pattern and list of standards, that will be the reengineering base, if identifying the nature and nomenclature of reengineering activities.

The capital construction facility reengineering pattern is identified by the organization chart of its implementation, as well as resource provision for reengineering measures (fig.3).

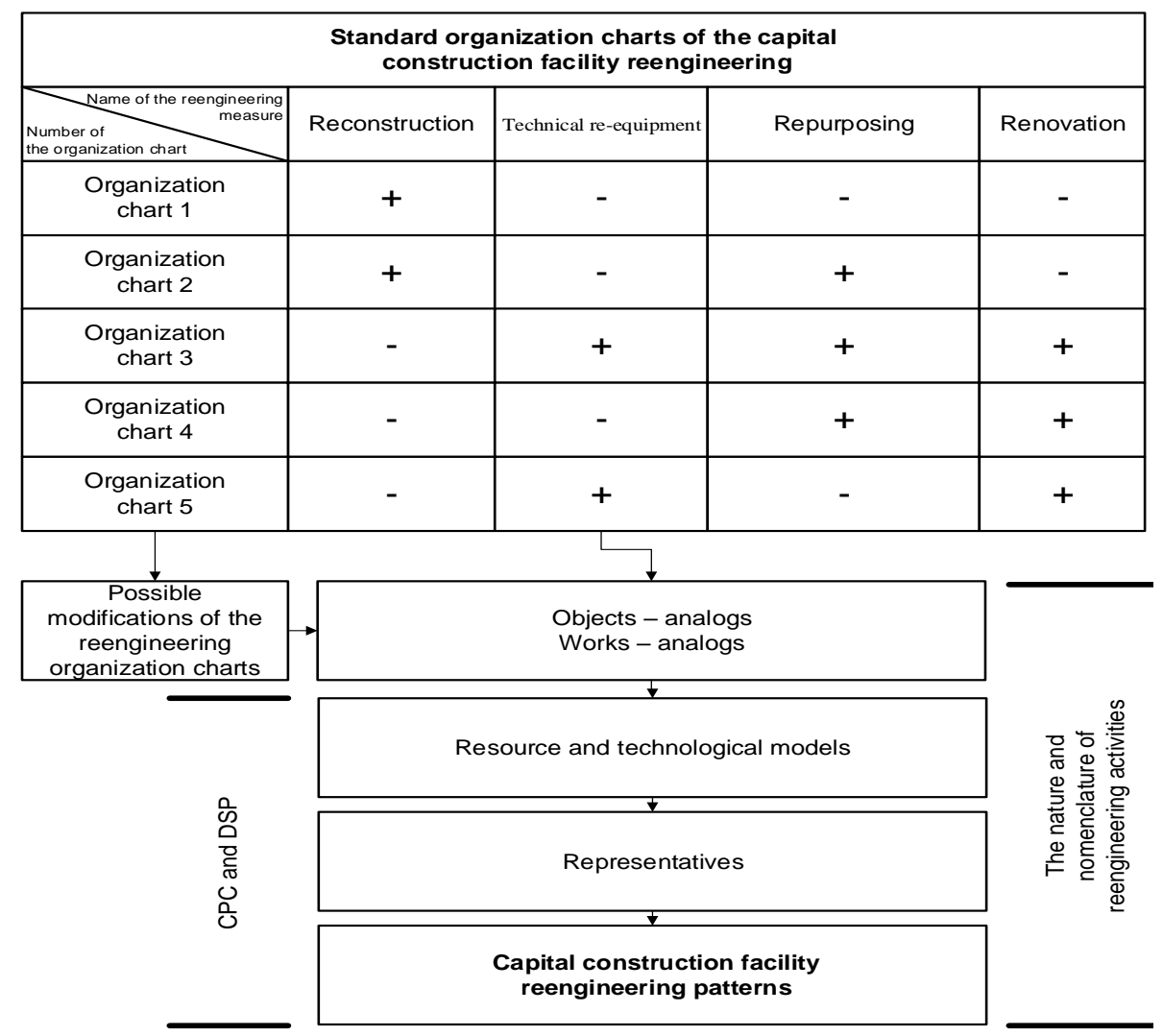

Fig.3. The scheme of formation of typical capital construction facility solutions

It is possible to highlight five standard organization charts of the capital construction facility reengineering; they are determined by the integration of restoration types and their activities' combinations.

The organization charts 1 and 2 are connected with the implementation of building or facility reconstruction, but the chart 2 assumes further object repurposing. Therefore, it is necessary to note, that during capital construction facility reconstruction its quality transformation happens due to changes in space planning and structure solutions, as a result of which not so much rebuilding of the capital construction facility to the required level is 
carried out, as its gaining higher consumer characteristics is. Along with this it may be stated, that such measures are sometimes not enough for a capital construction facility to be competitive and bring not only income, but also justify the maintenance costs. In this situation there is a topical issue of changing the purpose of the building, facility, i.e. its repurposing, for example, of the industrial and warehouse buildings to become commercial or entertainment ones due to extension of residential development and transfer of industrial zones outside the settlements.

Repurposing of the facility is also assumed in the organization charts 3 and 4 . But in case of the organization chart 3 it means changing of the production technology due to automation and robotization and by this forming a flexible automated production system. In case of implementation of the organization chart 4 repurposing of any non-competitive real estate object is carried out. However, in one way or another both organization charts assume the repair works - capital repair (renovation) of the building, facility.

The organization chart 5 describes a simple case of technical re-equipment implementation of an industrial enterprise, but which involves the elimination of damage to structures and finishing elements, caused by disassembly of old equipment and further installation and checkout of the new one. The elimination of such damage points at the necessity for special measures, renovation works.

It should be noticed, because of the variety of buildings and facilities, conditions of their operation, as well as their location there may be some modifications of the above organization charts of the capital construction facility reengineering, that subsequently may increase the nomenclature of the reengineering patterns.

An important element of the capital construction facility reengineering patterns is resource and technological modeling, which is based on the objects - analogs and works — analogs. It is necessary to mention, that such modeling is similar to the procedure the development of the consolidated indices, such as construction price standard (CPS) and design standards prices (DSP). Due to the fact, that serious shortage of the consolidated standards of the rebuilding measures is observed, the capital construction facility reengineering patterns, CPS and DSP may be developed simultaneously.

The development of the consolidated indices (CPS, DSP) is a part of the overall process of the capital construction facility reengineering standards development, affecting all its aspects (engineering, economic, management), and they may be divided into:

- common, describing integrated specific guidelines for reengineering implementation;

- developing, governing the creation, negotiation and approval of reengineering standards processes;

- applying, regulating the reengineering standards application.

Otherwise, the standards may be classified as industrial and corporate capital construction facility regulations. Industrial regulations, in their turn, may be divided into two groups:

1) current regulations, including both repair, reconstruction, technical re-equipment and erection standards, that may be applied with some modifications to the reengineering measures (i.e. respectively unchanged and requiring adjustments ones);

2) newly developing capital construction facility reengineering regulations, that are specific to this activity.

Such reengineering regulatory framework will facilitate to the development of the adequate and reasonable technical, technological, organizational, managerial solutions, aimed at the optimization of the capital construction facility operation process. 


\section{Discussion}

Capital construction facility reengineering and technological process reengineering, their reasons, structure, functions of the reengineering participants, distribution of competences between them and terminology of the reengineering measures, especially that ones, which are not defined in standards or have the opposite interpretation in different sources, are of greatest interest in the context of this research.

It appears, that the standards development process in reengineering will be implemented iteratively. At the first stage the creation of common industrial regulations and current documents adjustment for accounting the reengineering features are assumed. At the second stage specified industrial reengineering standards and corporate documents, regulating reengineering measures of the business entity, should be developed.

\section{Conclusion}

Based on the above it can be concluded, that reengineering mechanism efficiency directly depends on the quality of the informational and analytical work: promptitude, reliability, adequacy and sufficiency of the data for decision-making, type design, unification and standardization of the design, organizational and technological and management measures within the framework of the capital construction facility reengineering and technological process reengineering.

Formed on the basis of the above provisions system of the informational and analytical support of reengineering may give a serious impetus to the development and quality transformation of the capital construction facility. An effective functioning of the system of the informational and analytical support of reengineering is possible with an effective regulatory and teaching basis of its measures and adequate informational model of the capital construction facility at the stage of its operation. Cost reduction and shorter duration are possible with the development and use of the reengineering patterns, as well as productive complexes and telecommunications solutions.

\section{References}

1. Raizberg B.A., Lozovskii L.SH., Starodubtseva E. B. Sovremennyj ehkonomicheskij slovar' [Modern Economic Dictionary], 2 (corr.), 479 (1999)

2. Sborshchikov S. B. Logistika reguliruyushchikh vozdeystviy v investitsionnostroitel'noy sfere (teoriya, metodologiya, praktika): diss. dok. ekonom. nauk [Logistics of the regulatory impacts in an investment-constriction field (theory, methodology, practice): thesis of doctor of economic sciences] :08.00.05. Sergey Borisovich Sborshchikov; Rossiyskaya ekonomicheskaya akademiya im. G. V. Plekhanova [Pleckhanov Russian university of Economics]. - M., (2012). - 308

3. Lazareva N.V. and others. Ustoychivoye razvitiye investitsionno-stroitel'noy deyatel'nosti $\mathrm{v}$ energeticheskom sektore [Sustainability of the investment-construction field in the energy industry]; Vestnik grazhdanskikh inzhenerov [Bulletin of civil engineers], 2 (67), 269-275, (2018)

4. Shinkareva G.N. and others. Otsenka effektivnosti upravleniya realizatsiyey stroitel'nogo proyekta $v$ usloviyakh vozdeystviya sluchaynykh faktorov [Evaluation of the efficiency of the construction project implementation management under the influence of random factors]; Vestnik MGSU [Proceedings of the Moscow State University of Civil Engineering], v.12, no. 11 (110), 1240-1247, (2017) 
5. Leybman D.M. Strategicheskiy kontrolling - instrument obespecheniya ustoychivogo razvitiya investitsionno-stroitel'noy deyatel'nosti [Strategic controlling is an instrument of ensuring the sustainability of the investment-construction field]; Vestnik Belgorodskogo gosudarstvennogo tekhnologicheskogo universiteta im. V.G. Shukhova [Proceedings of the Belgorod State Technological University named after V.G.Shukhov], .2, 88-93, (2018)

6. Khripko T.V. Osobennosti realizatsii protsedur otsenki i otbora predlozheniy kontragentov v usloviyakh inzhiniringovoy skhemy upravleniya stroitel'stvom [Features of the implementation of evaluation and selection of counterparty proposals procedures in the conditions of the engineering construction management scheme]; BST: Byulleten' stroitel'noy tekhniki [BST - Bulletin of Construction Equipment], 12 (1000), 40-41, (2017).

7. Zhuravlev P.A. Tsena stroitel'stva i etapy yeye formirovaniya [The construction value and the stages of its formation]. Vestnik Irkutskogo gosudarstvennogo tekhnicheskogo universiteta [Proceedings of the Irkutsk National Research Technical University], 9 (104), 174-178, (2015)

8. Zhuravlev P.A., Kliuev V. D., Evseev V. G. Ispol'zovanie kvalimetricheskogo podhoda dlya ocenki konkurentosposobnosti investicionnyh stroitel'nyh proektov [Application of a qualimetric approach for assessing the competitiveness of the investment construction projects]; Nauchnoye obozreniye [Scientific Review], 8, 251-255, (2016)

9. Kliuev V. D., Levchenko A. V. Metodicheskij podhod k sozdaniyu informacionnoanaliticheskih sistem stoimostnogo monitoringa $\mathrm{v}$ stroitel'stve [Methodical approach to the development of the informational and analytical systems of value monitoring in construction]; Nauchnoye obozreniye [Scientific Review], 1, 214-218, (2014)

10. Yermolayev Ye.Ye. Osobennosti opredeleniya fiksirovannoy stoimosti stroitel'stva v ramkakh gosudarstvennykh programm [Features of determination of the fixed construction value within the framework of government programs]; Vestnik universiteta (Gosudarstvennyy universitet upravleniya) [Proceedings of the University (State University of Management)], 11, 35-38, (2013)

11. Aleksanin A.V. Perspektivnyye napravleniya razvitiya organizatsii stroitel'stva

[Prospective directions of the organization of construction]; Nauchnoye obozreniye [Scientific Review]; 10-1, 378-381, (2015)

12. Aleksanin A., Sborshikov S. Specifics of system of external influences on the life cycle of a construction object. In the collection: MATEC Web of Conferences " 5 th International Scientific Conference "Integration, Partnership and Innovation in Construction Science and Education», IPICSE 2016» DOI: 10.1051/matecconf/20168605013. (2016).C. 05013

13. Zharov YA.V. Uchet organizatsionnykh aspektov pri planirovanii stroitel'nogo proizvodstva $\mathrm{v}$ energetike [Consideration of the organizational aspects in planning of energy sector construction]; Zhurnal PGS [Industrial and civil engineering]; 5, 69-71, (2013)

14. Lazareva N.V. Teoreticheskie osnovy obespecheniya ustojchivogo razvitiya korporativnogo urovnya $\mathrm{v}$ stroitel'stve na osnove realizacii novyh organizacionnyh skhem upravleniya innovacionnoj deyatel'nost'yu [Theoretical bases of ensuring sustainability of the corporate level in construction through the implementation of the new organizational charts of the innovation activities management]; Vestnik Belgorodskogo gosudarstvennogo tekhnologicheskogo universiteta im. V.G. Shukhova [Proceedings of the Belgorod State Technological University named after V.G.Shukhov], 8, 55-60, (2018)

15. Shinkareva G.N. Model' inzhiniringovoj skhemy organizacii stroitel'stva v perspektive zhiznennogo cikla ob"ektov [Model of the engineering scheme of organization of 
construction in the perspective of the facilities' life cycle]; Vestnik MGSU [Proceedings of the Moscow State University of Civil Engineering], v.13, no.9 (120), 1090-1105, (2018)

16. Shinkareva G.N. Model' inzhiniringovoj skhemy organizacii stroitel'stva dlya kontraktov zhiznennogo cikla [Model of the engineering scheme of organization of construction for the life cycle contracts]; Vestnik MGSU [Proceedings of the Moscow State University of Civil Engineering], v.13, no.10 (121), 1204-1210, (2018)

17. Silka D. N. Sistemotekhnika proektnogo finansirovaniia $v$ stroitelstve aktualnye problemy i puti resheniia [Systems engineering of project financing in construction: actual problems and solutions]. In the collection: Sistemotekhnika stroitel'stva. Kiberfizicheskie stroitel'nye sistemy. Sbornik materialov seminara, provodimogo $v$ ramkah VI Mezhdunarodnoj nauchnoj konferencii [Construction systems engineering. Cyber-physical construction systems. Collection of materials of the seminar held in the framework of the VI International Scientific Conference], 221-224, (2018)

18. Lyapin A.V., Lyapin V.YU. Sovremennyy podkhod k organizatsii smetnoy deyatel'nosti V stroitel'stve [Modern approach to the estimated activity management in construction]. Nauchnoye obozreniye [Scientific Review], 8, 251-255, (2016)

19. Kliuev V. D., Zhuravlev P.A., Chabdarov M. M. Raschet finansovyh zatrat, neobhodimyh dlya realizacii regional'nyh programm kapital'nogo remonta obshchego imushchestva v mnogokvartirnyh zhilyh domah [Calculation of financial costs required for the implementation of regional programs for the overhaul of the common property in multi-apartment residential buildings]; Nauchnoye obozreniye [Scientific Review]; 22, 186-189, (2016)

20. Akchurin A. I., Plotnikov A. N., Plotnikov D. A., Shamenova G. R. Mekhanizm integral'noj ocenki sistemy upravleniya innovacionno-investicionnymi proektami [The mechanism of integrated assessment of the system of innovation and investment projects]; Under total ed. of the prof. A.N. Plotnikov, Saratov, (2015)

21. Lazareva N.V. Klasternaya model' organizacii innovacionnoj deyatel'nosti na korporativnom urovne $\mathrm{v}$ stroitel'stve: diss. kand. tehn. nauk [Cluster model of organization of innovation activities at the corporate level in construction: thesis of candidate of technical sciences]; Moscow State University of Civil Engineering, M, 185, (2015);

22. Sborshchikov S. B. Organizacionnye metody aktivizacii nauchno-tekhnicheskoj i innovacionnoj deyatel'nosti $\mathrm{v}$ stroitel'stve na osnove territorial'no-otraslevyh tekhnoparkov: diss. kand. tehn. nauk [Organizational methods of enhancing scientific, technical and innovation activities in construction on the basis of territorial and industrial technology parks: thesis of candidate of technical sciences]; Moscow State University of Civil Engineering, M, 167, (2000);

23. Zhuravlev P.A. Tsena stroitel'stva i etapy yeye formirovaniya [The construction value and the stages of its formation]. Text. Vestnik Irkutskogo gosudarstvennogo tekhnicheskogo universiteta [Proceedings of the Irkutsk National Research Technical University], 9 (104), 174-178, (2015) 